\title{
E a "Igreja caía na graça do povo": A pneumatologia como possibilidade de superação para o autoritarismo nas Igrejas cristãs
}

\author{
Orientador: Ana Maria de Azeredo Lopes Tepedino \\ Mestrando: Henrique Mendonça Machado \\ Área de Concentração: Teologia Sistemático-Pastoral
}

Linha de Pesquisa: Religião e Modernidade

O presente trabalho tem por objetivo demonstrar como o princípio de autoridade, fundamental para a subsistência de qualquer instituição ou organização humana, aos poucos, foi se confundindo e se associando as pessoas ou as instituições religiosas que o exerciam, culminando com o autoritarismo. Dessa forma, a ação do Espírito Santo que é o princípio vivificante e vivificador da Igreja de Cristo, gradativamente foi sendo cerceada ou pelo menos limitada na eclesiologia cristã. Por conseguinte, houve o enrijecimento das estruturas eclesiásticas contribuindo para um forte êxodo nas instituições religiosas. Todavia, o Espírito Santo que permanece e floresce como fundamento e espaço vital nas Igrejas cristãs trabalha a fim de que estas possam superar as formas de autoritarismo que produzem a morte, conseqüentemente, permitindo às Igrejas a amplidão e o alargamento do sentido da vida no Espírito, bem como, a renovação e o ressurgimento de uma Igreja mais humana e solidária. Isto é, um novo modo de ser Igreja capaz de manter acesa a chama de esperança por uma vida mais justa e igualitária, no coração de cada ser humano.

Palavras-chave: Autoridade; Autoritarismo; Eclesiologia; Espírito; Hierarquia; e Vida. 